\title{
A Probe into Absence of Students' Subjectivity in Maker Space in Art Colleges
}

\author{
Yingying $\mathrm{Hu}$ \\ International School \\ Huanghe Science and Technology College \\ Zhengzhou, China
}

\begin{abstract}
Nowadays, maker space not only means a new form of education business, but also a new culture. It is an important carrier for the development of the university innovation "culture". According to statistics, maker spaces on campus accounted for more than 60 percent, therefore, the extent of student participation directly affects the effectiveness and sustainable development of maker spaces, it is necessary to take a in-depth study of the maker spaces' subjectivity absence problem to realize the goal of "popular" entrepreneurship and innovation".
\end{abstract}

Keywords—university; maker space; subjectivity; absence

\section{INTRODUCTION}

A makers movement in colleges and universities has been gradually rising since maker space were brought into China in 2010. With the wave of "public entrepreneurship and innovation", the word "maker" was first written in the Chinese Government Work Report and caused great concern in 2015. It also has become an important part of innovation and entrepreneurship and education reform in higher education of China, and development of "maker space" in colleges and universities (maker space on campus for short in the following) is an important way to achieve higher innovation, entrepreneurship education.

The current development patterns of China's maker space are mainly: the first tier, maker space in large cosmopolitan, such as Beijing, Shanghai, Guangzhou and Shenzhen, got the rapid growth and fame in domestic and foreign fields with certain visibility and influence by the government's strong support; the second tier, maker space in some scientific and technological base of the capital cities started better, but they lack of systematic development and are lagging behind as a matter of restricted by the science and technology industrial base and new entrants constraints; the third tier, maker space on campus, which means relying on universities, especially formed in the arts institutions and technology industrial park. Onion Capsules in Hangzhou, as a typical domestic famous universities maker space, is the first maker space established by art college in China which created by the students of the Inter-media Art major in the Chinese Academy of Fine Arts College.

Onion capsules to keep her openness, creativity and environment friendly exchanges as well as hoping to develop maker space gradually into a publishing platform or workshops. The good and mature works Workshop are regularly placed on the website of Onion Capsules. Under such a release mode, students need to work with the attitude of the participants in the creation of works of art, just opposed to the previous project tracking publishing options.

General Secretary of China Xi Jinping pointed out that young people are the hope of the country and nation, social progress and innovation is the soul of entrepreneurship, which is also an important way to promote economic and social development and improve people's livelihood. Prime Minister $\mathrm{Li}$ Keqiang pointed out that to make everyone who wants to start, create something can have the opportunity, as the formation the situation of "public entrepreneurship and innovation" in China. All the Art colleges and universities across the country respond to these positively and have introduced measures to create a favorable ecological environment for innovation and entrepreneurship, in order to stimulate the creativity of the masses of college students, government and universities have been carrying out the depth of cooperation by the establishment of all kinds of cultural and creative public maker space, and hold many joint maker training camps.

On November 15, 2015, Chinese Academy of Fine Arts in 2015 and foreign art school held an international exchange activities, makers from France National Superior des BeauxArts, Delft University of Technology, the University of New South Wales, the Guangzhou Academy of Fine Arts, Sichuan Academy of Fine Arts and Zhejiang University and other institutions who feel close to a game screen painter's operation strategy, especially the pursuit of the details of the pursuit of quality, which also gives makers creating empathy.

Maker Space in Nanjing, founded more than one year, has the largest number of online members now is more than 220 , whose professional direction covering computers, electronics, architecture, art, machinery manufacturing, economic and many other fields with a goal that " zero threshold "for people who love life, love art and innovation to play and work together through a free exchange of the world, and jointly create a favorable atmosphere for innovation, as long as the students or the community of creative ideas, you can join. 


\section{The CONSTITUTION OF MAKER SPACE DEVELOPMENT IN COLLEGES AND UNIVERSITIES}

\section{A. The Main Developing Path}

The main developing path of maker space on campus is making full use of physical resources on campus such as space, equipment, tools, materials, and open management to create and construct public space to carry out the students' innovation, entrepreneurship education and support the innovation entrepreneurship education culture of universities. There are also a number of university libraries, training centers, special studio, laboratory or separate processing workshops have become the new platform and incubator for encouraging people to do business creatively and drive innovation by upgrading or renovation.

\section{B. The Main Subjects of the Maker Space on Campus}

The maker space basic logic operation is from the idea, then the creative thinking, to product. Therefore, the main subjects of the maker space on campus should include: students, mentors, manufacturers, and even need more comprehensive subjects including technology guidance or researchers in product testing, various staff packaging, promoting the related aspects of the patent application and protection etc. In this Multi-level, cross-mesh elements structure, students should and must be the subject of the maker space, which includes students on campus and the last two years graduates, they can communicate and interact face to face at the same time to fulfill some co operations. Makers play the spirit of innovation and knowledge role in this space through the exchange, collision, seminars, cooperation, innovation or personally creation to turn the fantasy into reality by hard work, highlighting the value of knowledge.

Currently in China, administrative departments at all levels from the national, provincial and municipal have introduced the relevant identified and management methods about maker space, but the most prominent problem is the low engagement of students besides the inadequate development potential. Mainly as follows: the students are lack of correct awareness by thinking it was just a kind of oligarchic party for some professional engineering or commercial projects; College blind following trend, they're undertaking their maker space in almost the same pattern without their own ideas in the operation; It was rush-style building and concealed its natural functions in the actual operation. Therefore the point is the absence of subjectivity problem, if no students in the maker space as the main body in colleges and universities, it ultimately bounds to become a ghost town after the construction trend.

\section{The Students' Absence CAUSES OF THE MAKeR SPACE DEVELOPMENT IN COLLEGES AND UNIVERSITIES}

\section{A. The Resistance of Students' Creative Thinking and Learning Habits}

The ultimate goal is to learn to use, and the use is a complex creative thinking and practice procedure. Therefore, creative thinking is an essential part in learning, work, life.
However, for a long time, the creativity and innovative thinking of Chinese students is under the pressure of the joint action between the traditional basic education system and the higher education recruitment rules, even entering university, it is still very difficult to adjust and accept this kind of creative thinking for most of us.

Learning mainly means to receive or input, and the majority active students in the maker space also rely on the guidance of a teacher or other related business. As a result, Year-off project or inspiration gradually formed will be not well implemented.

\section{B. The Top-level Design and Lack of Experience}

As a new thing, although there are many famous cases can draw, but maker space can hardly copy any version correctly, the location, design, capacity of the maker space can be different, but innovation and sharing need to be adhered to the core firmly. Online maker communication platform in colleges and universities is also maker space besides the physical space, but the problem is capital and operating expenses, followed by the organization and management system, the maker team composition, training, advocacy activities and cultural construction etc, so that, the top-level design managers and organizations experience problems difficulty of building soft power is much greater than the transformation of physical space, and in many colleges and universities, the maker space organization, training, support system, incubation, management are still in the early stage, there is no time to benefit student. When the Students come in the maker space as makers, in order to create customer identity into the record passenger space, how to find the proper project and mentor, how to promote employment, and how to jointly promote the development of maker space are urgently perfected.

\section{Management and Operation Issues}

As Maker space on campus provides makers space for the physical activity and hardware platforms; for the early entrepreneurs, which is really necessary for them to get welfare with high quality, low price of office space. While the year-off activities in the process of project research and practice need to try or error try, which caused some consumption in the process, it affect the management and operation of maker space, even a certain contradictions and conflicts, it is also in the dominant difficult position to achieve students participation.

Before the development of the maker space, we must first solve our own development, which is a more difficult reality. Students' subjectivity is still determined and weak as the maker culture is not yet widely recognized and respected from the community, businesses and parents, so is the maker space, to promote economic development, promote self-employment, and create a culture of innovation is very limited.

\section{STUdENT-CENTERED DEVELOPMENT STRATEGY}

Maker space on campus has the obvious research resources advantages as it can make full use of the professional expertise and interest of both teachers and students, which is bound to distribute and benefit the decentralized, personalized small and 
micro entrepreneurs. At the same time, colleges and universities create maker space and focus on the students as its subject to do innovation, entrepreneurship education and help the students get innovation, creativity, entrepreneurship training in advance, which is a win-win trend. For the absence problem of students' subjectivity in maker space, the following part will explore the strategy of college students' subjectivity.

\section{A. Scientific Coherent Education Philosophy and Creativity Cultivation}

Maker education definitely means to emphasis innovative thinking activity and making by hands, nonconformist, singular and change, this capacity-building needs the scientific, coherent education philosophy, and therefore we should continue to emphasize the reform of basic education for students' creative thinking training and jointly promote the formation of the education system in terms of curriculum, primary and secondary schools maker space development. Only change our education philosophy and the concept of talent, the education development bottleneck is broken, parents and teachers have a new self-concept to develop students' creative thinking, can our college students gradually form creative thinking and foster innovation.

Maker education, after all, is a kind of practical education which emphasis on innovation and hands-made education, therefore, innovative, creative thinking potential, knowledge and ability of creativity are all should be included as a continuous system, Different education period carries a different educational function, Innovation, creating and entrepreneurial practice education should be carried out throughout the whole educational system, forming such a successive maker education structure as the innovation literacy education in primary education, innovation and entrepreneurship education in higher education, and entrepreneurship education practice in the field of social Yearoff. in such a gene with innovative ecosphere, maker space on campus can be aggregated more real makers or students and create real customer to help them play their main role.

\section{B. Explore the Bidirectional Functions between Maker Space and the Teaching}

Innovative Education inspire, nourish makers while makers nurture, enrich education correspondingly. As makers' spirit and cultural education in higher education schools do not contradict theoretically, rather than the education system and universities innovation, entrepreneurship education system continue to remain in the phase mismatch, we should take the innovation, creativity and relevant skills as a habit for teaching to guide students to become creators or makers. Students in the context of creative education as makers have the absolutely selection autonomy for their own learning tasks, the path and resources, and they are learning with certain problems at the same time to solve the problem, they deeply get involved in the learning process which is much easier to generate new ideas.

Maker space in colleges and universities has a unique atmosphere and resource advantages, therefore, seize the students as the subject, to focus on the combination of business needs and personnel training in the development of higher education, as well as the interdisciplinary integration between the economic and social development, so the convergence of the professional education and innovation and entrepreneurship education in universities would be effective to drive the students under various professional backgrounds to come together and blend or reorganize knowledge, which helps to form creative team in colleges and universities, to inspire young people's creativity and passion and become the birthplace of new industries, through the interdisciplinary training for students and the division of labor role, achieving the real innovation as well as makers without borders.

\section{Draft the Management Standards and System of Maker Space and Extend Its Service}

Maker space on campus is lack of more mature business background, vast social resources and relevant experience compared with other forms, therefore, to fulfill the studentcentered development of maker space on campus, management organizers should provide the certain platform services with continuous functional expansion to be the escort for adapter connection. Maker space is non-profit, on one hand, Attractive measures and incentives are needed, correspondingly, supporting ways of the business contacts, business tax etc by expanding the guide and promotion of the transformation of scientific research and other service functions. These management details can be controlled by universities and college according to their own management system to carry out successive hierarchical implementation.

Management system of makerspace on campus College should treat students as the body, which includes students in school, various innovative projects teams, graduates and famous alumni who are more appropriate for university's professional development and social needs from individual emotion and professional cognition Modern society is a diversified investment era of crowdfunding, not being able to rely on an idea to attract investors. To get investment from angel investors have to do a business by money, but the probability of failure of student entrepreneurs or business is always greater than the probability of success. Letting motivated and more mature projects or business groups try in the form of online or real business, the ratio and proportion of success of makerspafce will be relatively large. Exempt students from worrying about failure, better promote the development of these newborn teams, and then better maintain the economic and ecological development of maker space on campus College.

\section{Open and Coalition Development of Maker Space on Campus}

As the subject groups of maker space on campus College, they are in need of sharing and cooperation a moment of having the most knowledge and innovation enthusiasm moments, therefore, it is important to adhere to the maker's spirit of commonweal, openness, service, research, international, which is based on modern communication technology, professional technical support, internationalization, real time to build the federated development pattern. Coalition Development of maker space on campus College is a shared 
mechanism. In addition to resources of software tools, computing power, manufacturing equipment, testing equipment, you can also share the results, action cases and promote collaborative projects, share "maker instructors".

Members do regular interaction and work together on the development of production equipment, personnel assignment, discussion, training and guidance, school-enterprise cooperation, creativity, demand publishing and collection of industrial innovation projects, promotional display of technological innovation and application results, carrying out creative, innovative and entrepreneurial contests such as a maker Carnival, a maker marathon, a maker athletics, a maker competitions and other activities. Building active creativity and entrepreneurial atmosphere of maker space on campus College contributes to "maker culture" in maker space to enrich and expand the effect of creating strong storm in practice field.

\section{REFERENCES}

[1] Zheng Yanlin, "On American University to implement Path Analysis of customer education," Open Education Research, No. 3Vol. 21, Jun. 2015

[2] Lawrence P. R. Andrews K. R. The Case of Teaching Human Relations and Administration M . Cambridge Harvard University Press 1953, pp. 271-350.

[3] Fu Qiang, "Based on the "Made in China" create customer education support ecological studies," No. 8Vol. 14, Nov. 2015.

[4] lv li, Fang Zhuqing and Qiao Hui, "Mass Entrepreneurship Theory and the Practice of Business Management and Innovation," Monthly Science and Technology Venture, No. 2Vol. 2, Feb. 2015 